Part 4. Studia Iuridica Lublinensia vol. XXVII, 1, 2018 DOI: $10.17951 /$ sil.2018.27.1.131

\author{
Marko Novak \\ Nova Univerza, Slovenia \\ marko.novak@evro-pf.si
}

\title{
Ensuring Uniform Case Law in Slovenia: Jurisprudence Constante, Stare Decisis, and a Third Approach
}

\begin{abstract}
Zapewnienie jednolitego prawa precedensu w Słowenii. Utrwalone orzecznictwo, stare decisis oraz trzecie ujęcie
\end{abstract}

\author{
SUMMARY
}

The judicial doctrine of jurisprudence constante is a civil-law equivalent of the common law doctrine of stare decisis. Both doctrines resulted from the $19^{\text {th }}$-century legal positivist movement criticizing the liberty of courts when deciding like cases. If stare decisis has developed into a normatively serious doctrine ensuring coherent and consistent adjudication, jurisprudence constante, however, did not go that far. After a short historical introduction regarding the development of both doctrines, this paper discusses their most important normative differences, provides reasons for these differences, and analyzes the problems that the civil-law doctrine presents in the Slovene legal system in particular, the possibility of transplanting the common law doctrine to our country, and the need for a third way approach to better ensure uniform case law in Slovenia.

Keywords: Slovenia; case law; jurisprudence constante; stare decisis; third approach

\section{INTRODUCTION}

Particularly in modern complex societies, uniform case law is of great importance in order for the constitutional principles of the rule of law and equality before to be seriously taken into consideration. Legal families and the legal systems within them have differently dealt with these issues, although nowadays from a first impression it seems that the approaches from common law and civil law to the legal institution of "precedent" are not that far from themselves when we consider the broadest meaning of that word. However, when we go into the details of how seriously precedents are followed we soon notice important differences. Thus 
the main idea of this paper is to analyze some of the most important differences between the common law doctrine of stare decisis and the civil law doctrine of jurisprudence constant and discuss advantages and disadvantages of both doctrines. As a matter of fact, there is more about the deficiencies of the civil law doctrine, as I claim here as well as in my other works on this topic that stare decisis is a better and more efficient doctrine.

In the paper, I present some of the most important steps in the historical development of both doctrines, mostly in England and France. Then I discuss the different constitutional entrenchment of stare decisis and jurisprudence constante. In the next part many problems with the civil law doctrine in the Republic of Slovenia are presented including the reforms that have already been made to improve the situation and those that have still been envisaged. At the end of this part, just before the conclusion of the paper, I also discuss some of the ideas of how to depart from the predominantly unsuccessful civil doctrine and come closer to stare decisis, but in a quite distinct civilian way.

\section{THE HISTORICAL ORIGIN OF THE CLASSICAL DOCTRINES}

The concept of jurisprudence constante has generally been used in a global literature when the civilian approach to considering previous typical (or model) judicial decisions in future cases (judicial "precedents") is distinguished from the common law approach. As a matter of fact it is a French expression which designates settled or established case-law (i.e. one of the meanings of jurisprudence is case law, and constante means constant, settled, established). In the mentioned literature it has become a generally accepted term for a series of judicial decisions in which courts adhere to a legal position that was taken in a previous case'.

Historically, the civil-law tradition has recognized statute as the primary source of law. It was France which had first adopted modern codifications (five of them), and where it was explicitly prohibited to use judicial precedents as judges had been doomed to only be mouthpieces of the law. Already to Montesquieu, it was the power of the legislature to make law and every judge was supposed to only be bouche de la $l o i^{2}$. In his famous work Montesquieu expressed the problems of his time so, from a normative perspective, he envisaged a solution. Thereafter his "spirit of the law" of a strict conception of the separation of powers was kept all the way through the Revolution due to general distrust of parlements (the then royal courts) that were manipulated by the French king before the revolution. Not only in France, but elsewhere in the then Europe, the ideals of certainty and com-

${ }^{1}$ In Germany this doctrine is, e.g., called ständige Rechtsprechung.

${ }^{2}$ C. Montesquieu, The Spirit of Laws, Ontario 2001. 
pleteness in the law implied that legislative provisions had to be formulated and interpreted as mathematical canons to avoid any room for discretion or arbitrary decisions by the judges"3.

However, in the course of the $19^{\text {th }}$ century, this "enlightened" illusion that the legislature is capable of regulating everything important and judges need only to mechanically apply the legal rule to the facts of a case was relaxed to some extent. Thus, as memories of the abuses of the pre-revolution regimes began to fade, ideological concerns over the judiciary's role were assuaged. In their own judicial practices, civil law jurisdictions gradually adhered to a system of informal precedent law, where a sequence of analogous cases acquired persuasive force as a source of law ${ }^{4}$. After all, equality before the law required some coherence and consistency otherwise the freedom of courts to decide like cases differently at their pure will would be intolerable.

At the same time, when the first civil codifications were being prepared on the European continent, also England could not escape a legal positivist movement that began to criticize "arbitrary" judiciary of the Middle Ages. That state of mind produced a reform from which two important doctrines were born: stare decisis (et non quita movere) and ratio decidendi. The idea of the first is that judges should stick to a position that they took in a previous case with the same legal question resolved and essentially similar facts present. The second brought the first even further and was its extension: it was not enough to follow a previous pattern case (precedent) but what was from then on considered binding from such a precedent was only that part of the case that was a subject of decision (including the decision and the essential facts of the case). This stemmed from the critique that common law judges had previously followed a "spirit" of the case ${ }^{5}$, not the "latter" of the same 6 .

As an important intellectual figure behind that reform movement in England was J. Bentham, who was known to be very critical about common law judges. Already in 1776, he published anonymously a vehement attack upon Blackstone's Commentaries (the most famous book about common law ever) and his interpretation of natural law. Also, he firmly maintained the desirability of the codification of the law in England, to help it escape from the arbitrariness of the judiciary, to clarify what law was, and to make it enforceable justly, in the sense that all men could know what its provisions were. He seems to have invented the very term 'codification' to describe the process of issuing a code?

${ }^{3}$ V. Fon, F. Parisi, Judicial precedents in civil law systems: A dynamic analysis, "International Review of Law and Economics" 2006, No. 26, pp. 519-535.

${ }^{4}$ Ibidem.

${ }^{5}$ K. Zweigert, H. Kötz, An Introduction of Comparative Law, Oxford 1998.

${ }^{6}$ M. Novak, Limiting Courts: Towards Greater Consistency of Adjudication in the Civil Law System, [in:] Logic, Argumentation and Interpretation, ed. J. Aguiló-Regla, Stuttgart 2007, pp. 95-106.

${ }^{7}$ O.F. Robinson, T.D. Fergus, W.M. Gordon, European Legal History, London 2000, pp. 254 255 . We also know that he even offered to help codify laws of the newly independent United States of 


\section{THE TWO DOCTRINES' DIFFERENT CONSTITUTIONAL ENTRENCHMENTS}

If we compare the two doctrines, namely jurisprudence constant and stare decisis, we must realize that the common law's version is stronger constitutionally entrenched than the civil law's counterpart. Stare decisis is not only considered as a part of but is almost synonymous with the rule of law stemming from the idea that if we follow previous model cases (i.e. legal precedents) the values of stability, predictability, certainty, and trust in the law are thereby ensured ${ }^{8}$. The rule of law as an idea is, in sensu lato, certainly a meta-legal value, a Grundnorm or a constitution itself.

Unlike common law, in civil law systems jurisprudence constante is usually understood as being constitutionally entrenched in articles dealing with the equality of law ${ }^{9}$. As a constitutional principle equality of law is also one of the pillars of modern constitutional systems, at least the ones from the times of bourgeois revolutions onwards. In many contemporary constitutions' texts equality of law comes after the rule of law, in some sense, it is derived from the rule of law as being the law itself.

The fact that the common law doctrine of stare decisis is stronger constitutionally entrenched than the civil law doctrine of jurisprudence constante is not surprising if we know the tradition and historical importance of judges, courts, and their case law in the legal consciousness of people in common law countries. Despite the globalization also in the area of law and some ideas on the legal academic market maintaining that the two greatest legal families have slowly been merging, it seems that at least in the aspect that I am dealing with here important differences between the two mentioned doctrines as applied in the two legal families still remain.

America in the $18^{\text {th }}$ century as he proposed to the then President Madison to write codification for the United States. See: R. David, G. Grasmann, Einführung in die großen Rechtssysteme der Gegenwart, München 1988.

8 The use of precedent is in the common law world generally justified by the following elements: predictability, reliability, equality, and efficiency. Moreover, it also helps harmonize and reconcile two ideals: stability and change. H. Abadinsky, Law and Justice: An Introduction to the American Legal System, New Jersey 2003, p. 37.

9 The Slovene Constitutional Court found it as being part of Article 22 of the Constitution of the Republic of Slovenia (Off. Gaz. RS, No. 33/91-I et seq.; for an English translation of the Constitution visit the official webside of the Constitutional Court at: www.us-rs.si) dealing with the right to the equal protection of right, stipulating the following: "Everyone shall be guaranteed equal protection of rights in any proceeding before a court and before other state authorities, local community authorities, and bearers of public authority that decide on his rights, duties, or legal interests". This constitutional right is considered to be derived from the constitutional principle of equality before the law from Article 14 of the Constitution. 
What do I mean by saying that the stare decisis doctrine is "normatively stronger" than its civil law's counterpart? I refer to its direct (or immediate) and erga omnes effects in the sense of its binding character, meaning that a typical or model previous decision of a higher court should in every essentially similar (in terms of the decision and the material facts of a case) subsequent case be followed by all inferior courts in the same jurisdiction as well as by the higher court that produced such a precedent decision. Certainly, in cases with different decisions and different material facts courts do not need to follow precedent decisions. Moreover, the higher court may depart from its precedent if it finds better reasons or social circumstances on the basis of which the case was decided before have changed.

Contrary to that, when the civil-law doctrine is considered, only a series of cases that were decided essentially similar constitutes settled or established case (i.e. constant jurisprudence) law that obliges future courts, in one way or another, to follow it. What distinguish it from the common-law doctrine are basically two issues that make it normatively weaker when compared with stare decisis: (1) no immediate or direct effect because it usually takes at least several cases ${ }^{10}$ before the case-law settles; and (2) weaker erga omnes effects to the effect that future courts officially recognizing only inter partes effects of judicial decisions do not always follow precedents consistently in future situations ${ }^{11}$.

But still, even in the framework of civil-law legal systems, jurisprudence constante contains certain elements resembling stare decisis in terms of their normative dimensions. There are certain instances of powers of civil-law courts that entail (i) direct and (ii) erga omnes legal effects of a single judicial decision. The first example is the power of constitutional review of constitutional courts or similar courts with a power to strike down a piece of legislation. In such a case only one decision is needed to have direct and erga omnes effect - in a similar manner as amending a statute through legislative procedure. The second example is a decision or opinion of the Court of Justice of the EU in the cases of preliminary rulings. It is a decision that has a direct binding effect and applies to virtually anyone (erga omnes) within the EU when it comes to the interpretation of an EU law provision.

In Slovenia as a civil-law country, as already hinted, the constant jurisprudence doctrine applies, which is one of the reasons why it faces many problems concerning the uniformity of case law. However, it seems that even if the common law doctrine is at some point transplanted to our country, which is quite unlikely for various reasons, it would not be an ultimate cure for all the ailments associated with the non-uniform case law. I discuss some of these issues in the following part.

${ }^{10}$ In Slovenia at least three cases according to the established position of the Constitutional Court.

${ }^{11}$ In Slovenia courts most often do not recognize case law as formally for future cases and even Constitutional Court decisions in consitutional-complaint cases, which thus deal with violations of individuals' fundamental rights, are often not considered as binding erga omnes. 


\section{SLOVENIA: THE NEED FOR A THIRD APPROACH}

When Slovenia and its legal system are concerned, it will follow below that the present situation of how our version of established case law works in practice to ensure the case law's coherence, consistency, equality before the law, and consequently rule of law, is far from ideal. Thus it seems more than necessary that it should be reformed. But in which direction?

Should we only upgrade the existing concept of jurisprudence constante with some kind of variants that would consider incorporating some stronger normative elements to make the doctrine more in tune with the principles of equality before the law and legal certainty? Or should we abandon the civil-law doctrine altogether and try to assume a kind of the common law version? Or, if the last idea would be too revolutionary to be interesting for a relatively stable political and legal system, if would be better to invent some new or third approach?

In this light, I first discuss potential variants of the existing system, and then, second, think about a third approach, taking into consideration that a complete incorporation of stare decisis into a civil-law legal system would be a too radical idea at present.

\section{Variants of jurisprudence constante}

The jurisprudence constante doctrine existed in Slovenia before and also during the communism. Courts have generally adhered to it, but it is a question how consistently they were in that. At the beginning of this century, the Slovene Constitutional Court elevated this doctrine to the constitutional level linking it with the fundamental right of the Equal Protection of Rights under Article 22 of the Constitution ${ }^{12}$. Since then the requirement that constant jurisprudence must be followed was considered as a fundamental right of a procedural character in the sense that if a court does not follow established case-law, if there is one, and does not even mention such in the reasoning of its decision a party may claim a violation of this fundamental right, by a constitutional complaint, because that court obviously acted arbitrarily. That means that this approach is only procedural so it means that a court can make a different decision, that is, depart from such established case-law as long as it mentions that there was established case law and provides reasons for a different decision. This means that the Constitutional

12 See supra. In this regard see, e.g., cases No. Up-121/96 dated 23 March 2000, Up-337/00 dated 26 February 2002, Up-207/00 dated 24 February 2002, and Up-337/00 dated 26 February 2002, at the official website of the Slovene Constitutional Court: www.us-rs.si. See also: M. Novak, Poglavja iz filozofije in teorije prava (Kultura precedensa), Nova Gorica 2008 (chapters: Philosophy and Theory of Law; Culture of Precedent), pp. 218-226. 
Court would not go into evaluating which court's position is more correct from a substantive point of view.

Although the above-mentioned approach is a step forward to ensure uniform case law in Slovenia, it is still too weak a doctrine to solve the major problems concerning Slovene non-uniform case law. The Constitutional Court has basically established that constant jurisprudence is formed through a series of equal decisions considering that only two consequent equal decisions do not already constitute established case law. Thus, in this Article I, claim for a stronger approach, one that would be close to stare decisis, and would provide some solution to the problem of especially the horizontal concept of settled jurisprudence in Slovenia, which is a major problem. The vertical concept of settled jurisprudence entails that lower courts follow case law established by higher courts, which is more or less the case in Slovenia as there are rare departures from this doctrine by lower courts, but the gravest problem in Slovenia is that there are many different decisions in essentially similar cases at the same level of courts (the so-called horizontal dimension of settled case law), which is intolerable.

According to the Slovene Courts Act ${ }^{13}$, it is the duty of the Supreme Court to ensure uniform case law. In order to ensure that two powers have been vested in it by legislation. The historically older one was the power to sit as a plenary and issue opinions of principle whenever they noticed some problems in terms of unsettled case-law. But there is problem with that power since the Supreme Court has not convened often for that reason, making this power quite inefficient in practice.

Another power that was vested in the Supreme Court several years ago, in order to better ensure uniform case law, was the possibility for it to admit revision (therefore "admitted revision") as a so-called extraordinary legal remedy from appellate courts. If parties to appellate judicial proceedings establish that in their case the case law of the appellate courts is not uniform, which can be detrimental to their case, they can file such a revision to the Supreme Court to make such case law uniform through its decision. The very idea was fine and the case law was indeed made more uniform, through the application of that remedy by the parties, but the problem is that, not only at the Supreme Court as a whole but also at its (five) different departments, there are different panels within each of the department often with different positions and decisions in essentially similar cases.

In the area of civil procedure, by the recent amendment to the Civil Procedure $\mathrm{Act}^{14}$, the importance of the so-called admitted revision, considering the fact that the regular revision as an extraordinary remedy in civil cases over a certain amount of money was abolished, was even more emphasized in order to give the Supreme Court additional opportunities for making case law more uniform. Although the

13 Off. Gaz RS, No. 19/94 et seq.

14 Off. Gaz. RS, No. 10/17. 
intention was positive, I am afraid that this additional effort will bring no better results for the above-mentioned reasons. Further, in my opinion, this amendment does not solve the problem because these revisions will be admitted by different panels of the Supreme Court that could still take decisions in essentially similar matters in an entirely different manner.

A similar problem concerning the divergent approach of different panels to same issues appears at courts of appeal in Slovenia. Although the country is being rather small and a unitary state, we have four appellate jurisdictions with four courts of appeal. This causes certain problems since regarding a same issue you often get different decisions even within one court of appeal, by different panels in their civil and criminal departments, without even mentioning the differences between the four appellate courts and their panels. There were some attempts through different ideas that the courts of appeal, or their departments, should organize joint meetings in order to try to make their case law more uniform. These meetings actually occurred but not in a systematic and consistent manner. And it was held that such divergence of positions was not that much due to lack of information that other judges or panels would have considering previous typical decisions, but more to firm positions of individual judges that would not be quite ready to depart from even when faced with the different positions of other judges of the same level that took such prior to the first judges.

Even if Slovenia decided to adopt the stare decisis doctrine, which according to the above said is quite unlikely, it would not solve its problem concerning the horizontal aspect. The horizontal stare decisis thus entails that courts of the same level are not mutually bound by their precedents. This could be a particular problem if in a jurisdiction there are several such courts that are often unwilling to cooperate. Although this could also be a problem in common law countries where stare decisis formally applies, it is a greater problem for a small size country such as Slovenia, which has four different courts of appeal. Thus potentially we can have four different decisions from these courts, and even every such court has several panels that can come to different decisions. That situation can also occur at the one Supreme Court, which incorporates several panels in its five departments.

In order to deal with such a problem, the Ministry of Justice in agreement with the Supreme Court has envisaged an amendment to the Courts Act ${ }^{15}$. The new idea that the Ministry is coming up with is the idea of "extended panels" of the Supreme Court. When deciding on a certain legal issue, if a single panel considers that such is important for ensuring uniform law application, it can decide that the case is to be decided by so-called "extended panel". It would normally do that if the resolution of a legal issue might entail departure from the constant jurisprudence of the Supreme Court or from a legal view of the extended panel, if the case law of the Supreme

15 The document is still an unofficial draft of that amendment. 
Court is not uniform in that area of law, or if the legal issue also falls within the power of deciding by another department of the Supreme Court, and if the prior attempt to coordinate and harmonize departments and the judges concerning the uniformity of case law was unsuccessful. The extended panel is to be composed of the judges of the deciding panel, five other judges and the president of the Supreme Court or his vice-president who presides over that panel. A viewpoint taken at such a panel is to be mandatory for all the panels of the Supreme Court.

\section{Beyond jurisprudence constante}

Frankly, the above said could solve some problems concerning non-uniform case law for Supreme Court panels but not for the panels of the courts of appeal if the case does not go all the way to the Supreme Court to establish case law in such a situation. Moreover, even Supreme Court judges would not be required to seek a decision by the extended panel, and I am sure there are other problems associated with this upgraded version of jurisprudence constante. The mentioned would be some improvement but the core problem would remain intact.

This is why, on the top of all the suggested ideas, it seems necessary that the Constitutional Court of Slovenia changes its interpretation of the constitutional clause of the Equal Protection of Rights, which as already mentioned includes some safeguards that constant jurisprudence will be adhered to. But it is completely helpless when there is a case outside the ambit of this doctrine, and that would, e.g., be the case when a same court panel is allowed to make two different decisions in an essential similar situation without even mentioning the previous one (remember, for case law to be considered established we need at least two same decisions). That is not already constant jurisprudence and judges are fully allowed to do that. For me, this is unreasonable if not unconstitutional and calls for a stricter interpretation of the mentioned clause by the Constitutional Court. I can understand that individual judges are horizontally independent from their peers' decisions, but what about the parties: is it right that they remain to endure the instances of completely different decisions by a court panel in two essentially similar cases. There needs to be a legal remedy to prevent such that parties could resort to in such situation in which they can claim a violation of the Constitution. That would give the parties an efficient remedy against "stubborn" and too individualistic judges.

Such a turn in considering the role of constant jurisprudence would certainly require constitutional legitimacy that needs to be made by the Constitutional Court. Does this mean introducing some kind of civil-law or human-rights stare decisis? Perhaps so but this is obviously very much needed at least in the Slovene legal system. In such a manner we will effectively solve the vertical problem of precedents, which frankly is already not such a problem, but will also be important for solving the horizontal problem. 
To deal with the horizontal issue of precedent, it would be useful that we adopt some kind of a system of preliminary ruling taking example from the Court of Justice of the European Union, which efficiently ensures uniform interpretation of EU law in member states. For example, if any judge faces a previous decision of any of his colleagues at the same level (considering the fact that they already follow precedents of higher courts and that this is not disputable as a matter of argument of authority) in a similar case and wants to make a different decision he or she would need to adjourn the proceedings, and submit the case to the already mentioned extended panel of the Supreme Court to take a decision and in such a manner decides which position is more acceptable.

\section{CONCLUSIONS}

From what was said above it is easy to conclude that when it comes to the coherence and consistency ${ }^{16}$ of case law as a basic requirement of the two constitutional principles mentioned above, namely the rule of law and the equality before the law, it is clear that the stare decisis doctrine is better off than jurisprudence constante. I guess not many jurists are quite happy in the civil-law world with case-law coherence.

Requiring courts to more thoroughly follow previous typical cases is to restrain their freedom to decide all cases anew. That might entail limiting their freedom (or independence) but if they more follow model decisions the coherence of their work would be improved, and thereby the entire institution of judiciary would benefit ${ }^{17}$.

My opinion is that an additional approach towards accepting some kind of stare decisis in the framework of civil law should be made, in order to solve the problems of a low level of case-law coherence and consistency that jurisprudence constante entails. For that reason, I suggested above a civil-law version that would help with the problem of the horizontal effects of precedents as well. A potential strengthen reliance on stare decisis in the civil-law world would not be an entirely new "battle", as I mentioned earlier some elements of stare decisis are already there, which had been fought for by constitutional courts and the Court of Justice of the European Union in the second part of the previous century ${ }^{18}$.

${ }^{16}$ Both coherence and consistency were claimed by N. MacCormick to be important principles within his idea of the second-order justification of judicial decisions. N. MacCormick, Legal Reasoning and Legal Theory, Oxford 1994, DOI: https://doi.org/10.1093/acprof:oso/9780198763840.001.0001, p. 119.

${ }^{17}$ For more of that view, see: M. Novak, Limiting Courts...

${ }^{18}$ See: idem, The Promising Gift of Precedents, [in:] Systems of Justice in Transition: Central European Experiences since 1989, eds. J. Přibáň, P. Roberts, J. Young, Aldershot 2003, pp. 94-108. 
Contrary to certain academic colleagues from the civil-law legal family, I am not that pessimistic about the possibility of development of a kind of the stare decisis doctrine in our legal family. If one doctrine is better working in practice why not try to apply it. I am aware of the fact that legal transplanting ${ }^{19}$ could be useless ${ }^{20}$ or even dangerous sometimes but there are also positive stories about that. One of them is certainly the legal transplant of 'plea bargaining' in criminal law from the accusatorial procedure to the inquisitorial (or at least nowadays mixed) procedure in a civil-law country as Slovenia. At some point, it was unthinkable that such a technique of "negotiation", originating from the general ideal that even in criminal procedure it is about resolving a conflict or dispute between the defendant and the state, would be relevant in continental criminal procedure that was found in the inquisitorial principle of seeking material truth. However, at least in Slovenia it was a success although there are still some legal issues to be dealt with, but about $50 \%$ of overall criminal cases are resolved in such a manner, which very much contributed to reducing court delays in the area of criminal law.

\section{REFERENCES}

Abadinsky H., Law and Justice: An Introduction to the American Legal System, New Jersey 2003. David R., Grasmann G., Einführung in die großen Rechtssysteme der Gegenwart, München 1988. Fon V., Parisi F., Judicial precedents in civil law systems: A dynamic analysis, "International Review of Law and Economics" 2006, No. 26.

MacCormick N., Legal Reasoning and Legal Theory, Oxford 1994,

DOI: https://doi.org/10.1093/acprof:oso/9780198763840.001.0001.

Montesquieu C., The Spirit of Laws, Ontario 2001.

Novak M., Limiting Courts: Towards Greater Consistency of Adjudication in the Civil Law System, [in:] Logic, Argumentation and Interpretation, ed. J. Aguiló-Regla, Stuttgart 2007.

Novak M., Poglavja iz filozofije in teorije prava (Kultura precedensa), Nova Gorica 2008 (chapters: Philosophy and Theory of Law; Culture of Precedent).

Novak M., The Promising Gift of Precedents, [in:] Systems of Justice in Transition: Central European Experiences since 1989, eds. J. Přibán̆, P. Roberts, J. Young, Aldershot 2003.

Robinson O.F., Fergus T.D., Gordon W.M., European Legal History, London 2000.

Watson A., Legal Transplants: An Approach to Comparative Law, University of Georgia Press, 1993. Zweigert K., Kötz H., An Introduction of Comparative Law, Oxford 1998.

19 A. Watson, op. cit.

${ }^{20}$ Quite known is the fate of the Ethiopian civil code, where after the decolonization of Ethiopia the famous scholar of comparative law, R. David, was asked to compose a civil code for that country, on the example of the French Code civil, which then resulted in more than 3,000 Articles, but the problem was that the code became to some extent applicable in urban areas only whereas the people from the rural parts of Ethiopia in their civil-law relations continued to stick to traditional legal customs instead. 
Pobrane z czasopisma Studia Iuridica Lublinensia http://studiaiuridica.umes.pl

Data: 26/04/2023 15:23:41

\section{STRESZCZENIE}

Doktryna prawna utrwalonego orzecznictwa (jurisprudence constante) jest cywilno-prawnym ekwiwalentem doktryny stare decisis w porządku prawnym common law. Obydwie narodziły się z XIX-wiecznego ruchu pozytywistycznego krytykującego swobodę sądownictwa w przypadku wydawania orzeczeń precedensowych. O ile stare decisis rozwinęła się w normatywnie ważką doktrynę, zapewniającą spójne i konsekwentne orzecznictwo, o tyle jurisprudence constante nie rozwinęła się w takim stopniu. W niniejszym artykule omówiono, po krótkim historycznym wstępie dotyczącym rozwoju obu doktryn, ich najbardziej istotne różnice pod względem normatywnym, wskazując zarazem ich przyczyny. Ponadto przeanalizowano problemy doktryny cywilno-prawnej, w szczególności w słoweńskim systemie prawnym, jak również możliwość przeniesienia doktryny na gruncie common law do Słowenii oraz potrzebę wdrożenia trzeciego, alternatywnego, podejścia w celu zapewnienia jednolitości prawa precedensu w tym kraju.

Slowa kluczowe: Słowenia; prawo precedensu; orzecznictwo utrwalone (jurisprudence constante); stare decisis; trzecie ujęcie 